\title{
СОВРЕМЕННАЯ ПРОБЛЕМАТИКА ПРЕДОСТАВЛЕНИЯ НАЛОГОВОГО ВЫЧЕТА ПО РАСХОДАМ ГРАЖДАН НА БЛАГОТВОРИТЕЛЬНОСТЬ
}

\author{
Е.А. Фирсова
}

\begin{abstract}
Раскрываются содержание и проблемы применения налогового вычета по налогу, взимаемому с доходов физических лиц, в части расходов, осуществленных на благотворительные цели. На основании анализа опыта различных стран в части такого налогового вычета оценивается его распространенность в мире, приводится классификация основных характеристик вычета, обобщается проблематика его налогового администрирования и контроля. Аргументированы причины недостаточной востребованности подобного вычета в России, предложены направления совершенствования законодательства для достижения большей эффективности налоговой поддержки частной благотворительности.
\end{abstract}

Ключевые слова: благотворительность, налоговый вычет, налоговая льгота, Республика Беларусь, Россия.

JEL-классификация: H24, H26.

DOI: $10.46782 / 1818-4510-2021-2-136-146$

Материал поступил 28.04.2021 2.

Благотворительная деятельность граждан, некоммерческих организаций и бизнес-структур является значимым фактором социального развития общества, а ее поддержка - необходимым направлением деятельности правительств всех стран. За последнее десятилетие масштаб благотворительной деятельности как физических, так и юридических лиц увеличился во всем мире, а в 2020 г. объем такой помощи даже возрос, несмотря на экономический кризис, вызванный пандемией.

Согласно исследованию ${ }^{1}$, посвященному изучению масштаба частной благотворительности в мире, в 2019 г. Российская Федерация находилась на 117 месте в рейтинге из 126 исследованных стран. Анализируя это достаточно низкое место в рейтинге, следует учитывать динамику развития частной благотворительности: если в 2010 г. помощь в виде передачи денег на

${ }^{1}$ CAF: World giving index. 10th edition. Ten years of giving trends. October, 2019. URL: https://www.cafonline.org/ docs/default-source/about-us-publications/caf_wgi_10th_ edition_report_2712a_web_101019.pdf цели помощи нуждающимся оказывало только 6\% населения России, то спустя 10 лет - в 2 раза больше. Отчет «Частные пожертвования в России 2020» ${ }^{2}$ содержит более детализированное изучение тенденций в сфере благотворительности и показывает, что в 2019 г. почти половина (49\%) россиян совершали денежные пожертвования, при этом их средняя сумма в год составила 3000 руб. (в 2018 г. - 2000 руб.). Большая часть денежных пожертвований проводится через платежи онлайн, поэтому дополнительным источником информации о масштабах благотворительности являются исследования банков, посредством которых осуществляются пожертвования. Так, в соответствии с данными Сбербанка ${ }^{3}$, в 2019 г. клиенты банка перечислили в благотвори-

${ }^{2}$ Исследование частных пожертвований в России 2020. Обзор тенденций частной благотворительности в России. URL: http://dev.cafrussia.ru/storage/files/file-105.pdf ${ }^{3}$ В 2019 г. клиенты Сбербанка перечислили в благотворительные фонды 6,5 млрд руб. URL: https:// www.sberbank.ru/ru/press_center/all/article?newsID $=801 \mathrm{f} 8$ d 68 - a 7 b $1-4$ c $28-8857$ - a 99 c 4 a a 3453 b \& block I D $=1303$ \&regionID $=77 \&$ lang $=$ ru\&type $=$ NEWS

* Фирсова Елена Анатольевна (firsova.e@unecon.ru), кандидат экономических наук, доцент, Санкт-Петербургский государственный экономический университет (г. Санкт-Петербург, Россия). 
тельные фонды 6,5 млрд руб. Кроме того, граждане в благотворительных целях перевели на карты физических лиц еще 7,4 млрд руб., и эти трансакции имели все признаки частных пожертвований. Таким образом, только через Сбербанк благотворительная помощь составила почти 14 млрд руб. Более точный способ определить суммы благотворительной помощи, оказываемой населением, чем через опросы населения и анализ банковских трансакций, в настоящее время в России доступен только уполномоченным государственным органам, так как открытые источники информации очень ограничены, а из 10,9 тыс. благотворительных фондов, зарегистрированных на сайте Министерства юстиции РФ на конец 2019 г., отчеты о своей деятельности опубликовали всего 4,2 тыс. организаций (38\%) $)^{4}$.

Беларусь в рейтинге стран по уровню развития частной благотворительности за 2019 г. находится выше России и занимает 92 место $^{5}$ - четверть населения страны участвует в различных формах благотворительной и волонтерской деятельности, в том числе $18 \%$ граждан оказывают помощь нуждающимся, переводя деньги соответствующим некоммерческим организациям. В 2010 г. такие денежные пожертвования совершали 11\% жителей страны, т. е. в Беларуси, как и в России, увеличивается число частных лиц, перечисляющих собственные сбережения на благотворительные цели. Более детализированные данные содержатся в аналитическом отчете «Анализ рынка благотворительности и мотивов осуществления пожертвований в Беларуси» ${ }^{6}$. Согласно исследованию, в 2018 г. 91\% белорусов оказывали безвозмездную помощь, при этом денежные пожертвования совершали $68 \%$ из них и средняя сумма таких пожертвований составила 78 бел. руб. При сопоставлении средней суммы пожертвований в России и Беларуси в пересчете по актуаль-

\footnotetext{
${ }^{4}$ Благотворительность накануне коронакризиса. URL: https://rusfond.ru/navigator_stat/10

${ }^{5}$ CAF: World giving index. 10th edition. Ten years of giving trends. October, 2019. URL: https://www.cafonline.org/ docs/default-source/about-us-publications/caf_wgi_10th edition_report_2712a_web_101019.pdf

${ }_{6}^{-}$Результаты анализа рынка благотворительности и мотивов осуществления пожертвований в Беларуси, проведенного ООО «ЦСБТ САТИО». URL: https://drive.google. com/file/d/1QhUffo_dFMUol2k9Ffgo4h1eSRI6DQyx/view
}

ному в 2018 г. курсу валют суммы благотворительной помощи россиян и белорусов примерно одинаковы. По оценкам экспертов, общий объем денежных пожертвований населения Беларуси за 2018 г. составил 43,7 млн евро (примерно 100 млн бел. руб., или 330 млн руб.). Таким образом, как в России, так и в Беларуси выявляются одинаковые тенденции увеличения числа частных лиц, переводящих денежные пожертвования через благотворительные организации и напрямую нуждающимся, при этом объем таких пожертвований достаточно велик.

В России поощрение благотворительной деятельности закреплено Конституцией РФ, а нормативно-правовое регулирование сферы благотворительности основано на нескольких федеральных законах и множестве подзаконных актах. В развитие положений Конституции в России утверждена Концепция содействия развитию благотворительной деятельности на период до 2025 г.7, в которой определены, в числе прочего, и направления государственной поддержки данной сферы. Конституция Беларуси не содержит норм, указывающих на поощрение благотворительности в стране, а нормативно-правовое регулирование благотворительности основано на положениях Гражданского кодекса Республики Беларусь (в части статей о дарении и ее разновидности - пожертвовании). Следует отметить, что в обеих странах налоговое законодательство содержит нормы, регламентирующие особенности исчисления налогов получателями благотворительной помощи и лицами, ее оказывающими.

В отношениях, связанных с благотворительностью, возникают определенные налоговые последствия, зависящие, во-первых, от того, кем является субъект налоговых правоотношений - получателем помощи или лицом, ее оказывающим. В случае, если физическое лицо получает помощь, то возникает вопрос о необходимости уплаты с нее налогов, установленных законодательством страны. Национальное налоговое законодательство может содержать перечень

7 Распоряжение Правительства РФ от 15 ноября 2019 г. № 2705-р «О Концепции содействия развитию благотворительной деятельности в РФ на период до 2025 г.». 
доходов, подпадающих под критерии благотворительной помощи и исключаемых из обложения. Налоговым законодательством обеих стран установлен перечень доходов, имеющих характер благотворительности, освобождаемых от обложения при получении их физическими лицами. Например, в соответствии с Налоговым кодексом Республики Беларусь ${ }^{8}$, освобождается от уплаты подоходного налога с физических лиц безвозмездная (спонсорская) помощь, а также поступившие на благотворительный счет, открытый в банке, пожертвования, полученные инвалидами, детьми-сиротами и детьми, оставшимися без попечения родителей, в размере, не превышающем 15030 бел. руб. в сумме от всех источников в течение налогового периода. В России действует похожая норма: освобождаются от уплаты налога на доходы физических лиц доходы в виде благотворительной помощи, получаемые детьми-сиротами, детьми, оставшимися без попечения родителей, и детьми, являющимися членами семей, доходы которых на одного члена не превышают прожиточного минимума, независимо от источника выплаты ${ }^{9}$. Есть и иные виды доходов физических лиц, имеющие характер благотворительности, освобожденные от налогообложения в Беларуси и России.

В случае, если физическое лицо оказывает благотворительную помощь, национальным налоговым законодательством с целью поддержки этой деятельности могут быть установлены налоговые преференции различного вида. В специальной литературе мало публикаций, посвященных данному вопросу, и в основном их авторы отмечают важность налогового стимулирования благотворительности. Так, обосновывается введение налоговых вычетов на благотворительность в России (Kireenko, Golovan, 2016. Р. 112), анализируется зарубежный опыт в данной сфере (Горский, 2020. С. 7579), дискутируется вопрос о том, должно ли национальное налоговое законодатель-

${ }^{8}$ Ст. 208 п. 29 НК РБ. URL: https://etalonline.by/ document/?regnum $=$ hk0900071

${ }^{9}$ Ст. 217 п. 26 НК РФ. URL: http://www.consultant.ru/ cons/cgi/online.cgi? rnd $=64 \mathrm{C} 0 \mathrm{AF} 2627 \mathrm{BCF} 79 \mathrm{AF} 05 \mathrm{CDBAC} 4 \mathrm{~EB}$ $47955 \&$ base $=$ LAW \& $\mathrm{n}=371946 \& \mathrm{dst}=4294967295 \&$ cacheid $=$ 8A696156EC8EF5A2028B995E8CEBFFDB\&mode=rubr\&req $=$ doc $\# 042505287133627245$ ство предоставлять вычеты по благотворительности, оказанной из-за рубежа (Yanni Zeng, 2019. PР. 61-65). В данной статье сделан акцент именно на мерах налогового стимулирования частной благотворительности, выражающейся в передаче имущества, в том числе денежных средств.

Содействие благотворительным инициативам населения налоговыми методами широко распространено в мире, поскольку благотворительность является не только одной из социально значимых сфер жизни общества многих стран, но и существенным сектором экономики. Так, в США действует почти миллион государственных благотворительных организаций и частных фондов, в которых работает примерно каждый четвертый работник. Соответственно, через сектор благотворительности аккумулируется и перераспределяется значительный объем финансовых ресурсов, а многочисленные доноры благотворительных организаций пользуются налоговыми преференциями, позволяющими снизить свой подоходный налог.

Проанализируем преференции, предусмотренные налоговым законодательством разных стран мира и предоставляемые физическим лицам, осуществляющим пожертвования в пользу нуждающихся ${ }^{10}$.

Налоговые преференции частным благотворителям могут быть классифицированы с применением определенных критериев.

1. По применяемому механизму:

- налоговый вычет - суммы, направленные на благотворительность, уменьшают налоговую базу по налогам, подлежащим уплате с доходов; этот механизм является наиболее употребительным в мире и используется, например, в Аргентине, Бельгии, Болгарии, Великобритании, Германии, Греции, Дании, Индии, Испании, Италии, Канаде, Китае, Мексике, Нидерландах, Польше, Португалии, США, Финляндии, Чехии, Швейцарии, Японии;

${ }^{10}$ Вся информация, характеризующая законодательство зарубежных стран, представлена на основе Обзора законодательства по налогообложению заработной платы Организации экономического сотрудничества и развития «Taxing Wages 2020» OECD iLibrary. URL: https://www.oecd-ilibrary.org/sites/ 047072cd-en/1/1/index.html?itemId=/content/publication/ 047072cd-en\&_csp_=61 ab1636a3c5e6e66df4c2ea29c39562\& 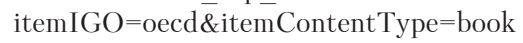 
- налоговый кредит - суммы, направленные на благотворительность, уменьшают сумму налога, подлежащую уплате с доходов; применяется в Венгрии, Израиле, Румынии, Франции.

2. По кругу лиц, в чей адрес могут быть перечислены благотворительные взносы, подлежащие льготированию:

- широкий круг получателей - суммы пожертвований подпадают под действие налоговых преференций в случае, если они направлены различным некоммерческим организациям, соответствующим определенным требованиям. Например, во Франции льготируются взносы квалифицированным благотворительным, образовательным, научным, социальным, религиозным, политическим или культурным организациям, профсоюзам и некоммерческим организациям, признанным общественно полезными, а также ассоциациям, уполномоченным оказывать помощь компаниям, испытывающим трудности, или компаниям с числом сотрудников менее 50. В Португалии льготируются пожертвования не только музеям, библиотекам, школам, институтам, образовательным или исследовательским ассоциациям, но и органам власти. В Чехии под действие налоговых льгот подпадают пожертвования с целью финансирования науки, образования, культуры, перечисленные частным лицам;

- узкий круг получателей - льготируются пожертвования только определенным организациям; например, только благотворительным организациям (Канада, Кипр, Нидерланды, Чехия), только определенным религиозным организациям (Италия, Польша), только университетам с государственным финансированием, при этом целью пожертвования должно быть развитие науки или искусства (Финляндия).

3. По законодательству, содержащему критерии определения получателей средств, пожертвования которым могут быть льготированы:

- гражданское законодательство, регулирующее деятельность некоммерческих организаций. В большинстве стран критерии отнесения организации к некоммерческой, в том числе благотворительной, содержатся вне налогового законодательства и применяются для целей налогообложения. Например, в Великобритании деятельность траста или группы лиц, созданной только для благотворительных целей, регламентируется отраслевым законодательством, а налоговые органы осуществляют контроль правомерности применения налоговых вычетов;

- налоговое законодательство - критерии определения получателей пожертвований, по которым могут быть применены льготы, содержатся в налоговом законодательстве. Например, в Аргентине под налоговый вычет подпадают только те благотворительные взносы, которые были направлены организациям, освобожденным от налогообложения; в Австралии - организациям, которые специально указаны в налоговом законодательстве или одобрены Комиссаром по налогообложению; в Дании благотворительные организации должны быть специально зарегистрированы в налоговых органах, чтобы их доноры могли получить налоговые вычеты.

4. По резидентству получателя помощи:

- только отечественные организации льготируются только пожертвования лицам, являющимся резидентами страны (например, в Великобритании, Венгрии, Китае, Швейцарии);

- как отечественные, так и зарубежные организации - льготируются пожертвования резидентам любых стран (например, в Германии).

5. По типу предела ограничений:

- установлен максимум - налоговым законодательством определена максимальная величина льготируемых пожертвований (в большинстве стран, например Австрии, Аргентине, Болгарии, Великобритании, Венгрии, Германии, Греции, Индии, Испании, Италии, Канаде, Китае, Мексике, Норвегии, Польше, Португалии, Румынии, США, Турции, Франции, Швейцарии, Японии);

- установлен минимум - определен минимальный размер суммы пожертвований, при превышении которого суммы подлежат льготированию (например, в Австралии и Дании);

- установлен и максимум, и минимум - определены границы сумм пожертвований, подлежащих льготированию (напри- 
мер, в Бельгии, Израиле, Нидерландах, Финляндии, Чехии).

6. По форме ограничений предельного размера сумм льготируемых пожертвований:

- ограничения выражены в процентах от дохода физического лица, полученного за налоговый период, или налоговой базы (табл. 1);

- ограничения выражены в абсолютной сумме (табл. 2);

- комбинированные ограничения (табл. 3).
Кроме перечисленных характеристик, в каждой стране есть дополнительные особенности предоставления налоговых вычетов или налогового кредита по пожертвованиям физических лиц. Так, требования к таким пожертвованиям, претендующим на получение налоговых преференций, могут быть сформулированы не только центральным (федеральным) уровнем власти, но и местным законодательством (Япония). Обычно право на получение льгот по благотворительности имеют только налоговые

Таблица 1

Предельные размеры налогового вычета или налогового кредита по благотворительным пожертвованиям, выраженные в процентах, в разных странах мира

\begin{tabular}{|c|c|}
\hline Страна & Предел налогового вычета (налогового кредита) \\
\hline Болгария & 65\% общей годовой налогооблагаемой базы \\
\hline Германия & $20 \%$ скорректированного валового дохода \\
\hline Индия & $\begin{array}{l}\text { От } 50 \text { до } 100 \% \text { от суммы пожертвований; вычет пожертвований, превышающих } 2000 \\
\text { индийских рупий, разрешается только в случае, если пожертвование осуществляется не } \\
\text { наличными }\end{array}$ \\
\hline Канада & $\begin{array}{l}15 \% \text { от первых } 200 \text { канадских долларов пожертвований и 29\% от сумм, превышающих } \\
200 \text { канадских долларов, за исключением жертвователей с налогооблагаемым доходом, } \\
\text { превышающим } 210371 \text { канадский доллар, для которых максимум вычета } 33 \% \text {, } \\
\text { но не более } 75 \% \text { чистого дохода }\end{array}$ \\
\hline Китай & 30\% налогооблагаемого дохода \\
\hline Португалия & $\begin{array}{l}25 \% \text { от суммы пожертвований в пользу государственных органов, фондов без } \\
\text { ограничений по максимальной сумме и не более } 15 \% \text { пожертвований, сделанных } \\
\text { другим организациям }\end{array}$ \\
\hline Румыния & 3,5\% годового подоходного налога \\
\hline США & $\begin{array}{l}\text { 100\% скорректированного валового дохода по пожертвованиям, отвечающим } \\
\text { определенным критериям; в иных случаях - } 60 \%\end{array}$ \\
\hline Франция & $\begin{array}{l}\text { До 66\% пожертвований; по взносам в ассоциации, предоставляющие бесплатное } \\
\text { питание нуждающимся - налоговый кредит в размере } 75 \% \text { для взносов до } 552 \text { евро }\end{array}$ \\
\hline
\end{tabular}

Источник. Обзор законодательства по налогообложению заработной платы Организации экономического сотрудничества и развития «Taxing Wages 2020» OECD iLibrary. URL: https://www.oecd-ilibrary.org/sites/047072cd-en/1/1/ index.html?itemId=/content/publication/047072cd-en\&_csp_=61ab1636a3c5e6e66df4c2ea29c39562 \&itemIGO=oecd\&itemContentType=book; Обзор законодательства по налогам юридических и физических лиц в 152 странах мира. Worldwide Tax Summaries Online. URL: https://taxsummaries.pwc.com/

Таблица 2

Ограничения размеров налогового вычета или налогового кредита по благотворительным пожертвованиям, выраженные в абсолютной сумме, в разных странах мира

\begin{tabular}{|l|l|}
\hline \multicolumn{1}{|c|}{ Страна } & \multicolumn{1}{c|}{ Предел налогового вычета (налогового кредита) } \\
\hline Австралия & Минимум 2 австралийских доллара \\
\hline Дания & Максимум 16 600 датских крон \\
\hline Италия & Максимум 1032,91 евро \\
\hline Норвегия & Максимум 50 000 норвежских крон \\
\hline Финляндия & Минимум 850 евро и максимум 500 000 евро \\
\hline
\end{tabular}

Источник. Обзор законодательства по налогообложению заработной платы Организации экономического сотрудничества и развития «Taxing Wages 2020» OECD iLibrary. URL: https://www.oecd-ilibrary.org/sites/047072cd-en/1/1/ index.html?itemId=/content/publication/047072cd-en\&_csp_=61ab1636a3c5e6e66df4c2ea29c39562\&itemIGO= oecd\&itemContentType=book; Обзор законодательства по налогам юридических и физических лиц в 152 странах мира. Worldwide Tax Summaries Online. URL: https://taxsummaries.pwc.com/ 
Ограничения размеров налогового вычета или налогового кредита по благотворительным пожертвованиям, выраженные как в абсолютной сумме, так и в процентах, в разных странах мира

\begin{tabular}{|l|l|}
\hline \multicolumn{1}{|c|}{ Страна } & \multicolumn{1}{|c|}{ Предел налогового вычета (налогового кредита) } \\
\hline Австрия & $\begin{array}{l}400 \text { евро в год; на определенные цели (исследовательские и гуманитарные цели, защиту } \\
\text { окружающей среды, пожарные команды, гражданскую защиту и т. п.) - до 10\% от } \\
\text { дохода }\end{array}$ \\
\hline Бельгия & $\begin{array}{l}\text { Минимум 40 евро, но не более 10\% от чистого налогооблагаемого дохода и не более } \\
397850 \text { евро (на 2020 г.) }\end{array}$ \\
\hline Израиль & $\begin{array}{l}35 \% \text { от пожертвований, которые в совокупности составляют не менее } 190 \text { шекелей, при } \\
\text { условии, что пожертвования не превышают 30\% годового налогооблагаеого дохода } \\
\text { и не более 9 350 000 шекелей (на 2020 г.), в зависимости от того, что меньше }\end{array}$ \\
\hline Нидерланды & Минимум 1\% дохода и более 60 евро, максимум 10\% дохода \\
\hline Чехия & $\begin{array}{l}\text { Не более 30\% от налоговой базы при условии, что общая сумма пожертвований } \\
\text { превышает 2\% налоговой базы либо составляет не менее } 1000 \text { чешских крон }\end{array}$ \\
\hline Япония & Минимум 2000 йен, но не более 40\% дохода, за вычетом 2000 йен \\
\hline
\end{tabular}

Источник. Обзор законодательства по налогообложению заработной платы Организации экономического сотрудничества и развития «Taxing Wages 2020» OECD iLibrary. URL: https://www.oecd-ilibrary.org/sites/047072cd-en/1/1/ index.html?itemId=/content/publication/047072cd-en\&_csp_=61ab1636a3c5e6e66df4c2ea29c39562\&itemIGO= oecd\&itemContentType=book; Обзор законодательства по налогам юридических и физических лиц в 152 странах мира. Worldwide Tax Summaries Online. URL: https://taxsummaries.pwc.com/

резиденты страны, но возможно получение преференций и нерезидентами (Нидерланды). Налоговый вычет может распространяться только на доходы, облагаемые по основной ставке, но также применяться и ко всем категориям доходов (Китай). Национальным законодательством устанавливается очередность вычетов: вычет на благотворительность применяется после того, как были испльзованы все остальные льготы и вычеты (Австралия). В некоторых странах вычет может быть перенесен на будущее (например, на 3 года в Израиле и на 5 лет в Канаде).

Интересным является опыт Венгрии, где налоговым законодательством установлен механизм благотворительности, увязанный с уплатой подоходного налога. По желанию физического лица 1\% от начисленной суммы налога может быть направлен в качестве взноса в благотворительную организацию или церковь, а не в государственный бюджет.

Налоговое законодательство стран Евразийского экономического союза не содержит каких-либо преференций для физических лиц, осуществляющих пожертвования на благотворительные цели. Исключение Российская Федерация, где с 2001 г. действует социальный налоговый вычет, одним из направлений которого является уменьшение налоговой базы на сумму до- ходов, перечисляемых налогоплательщиком в виде пожертвований благотворительным, социально ориентированным некоммерческим организациям; некоммерческим организациям, осуществляющим деятельность в области науки, культуры, физической культуры и спорта, образования, просвещения, здравоохранения, защиты прав и свобод человека и гражданина, социальной и правовой поддержки и защиты граждан, содействия защите граждан от чрезвычайных ситуаций, охраны окружающей среды и защиты животных; религиозным организациям на осуществление ими уставной деятельности; некоммерческим организациям на формирование или пополнение целевого капитала. Вычет предоставляется в размере фактически произведенных расходов, но не более 25\% суммы дохода, полученного в налоговом периоде и подлежащего налогообложению. При этом в определенных НК РФ случаях предельный размер вычета может быть увеличен законом субъекта РФ до 30\%. Таким образом, в России по налогу на доходы физических лиц действует налоговый вычет для благотворителей по правилам, обычно применяемым за рубежом.

Как было рассмотрено выше, объем благотворительной помощи, оказываемой физическими лицами в РФ, достаточно велик и имеет тенденцию роста. В связи с 
этим представляется интересным проанализировать количество налогоплательщиков, воспользовавшихся правом на вычет. Динамика основных показателей, характеризующих практику применения данного налогового вычета за 11 лет, представлена в табл. 4.

Как видим, количество налогоплательщиков, которым предоставлены социальные налоговые вычеты по пожертвованиям, за 11-летний период возросло в 2,4 раза, в то время как число всех налогоплательщиков, представивших налоговую декларацию, увеличилось лишь на 47\%. Однако даже при таком значительном темпе роста в среднем за 11 лет за вычетом на благотворительность обратились лишь 0,09\% всех налогоплательщиков, представивших налоговую декларацию. Если учесть результаты опросов, приведенных выше и показывающих, что в 2019 г. половина россиян осуществ- ляла перечисления средств на благотворительность, то по данным ФНС из них чуть менее 10 тыс. чел. собрали комплект подтверждающих документов и отразили в налоговой декларации свое право на вычет. Сумма вычета, отраженная в декларациях, составила 3,95 млрд руб., при этом только через Сбербанк были осуществлены денежные переводы в порядке благотворительности в сумме почти 14 млрд руб. Цифры свидетельствуют о том, что вычет на благотворительность не очень востребован российскими налогоплательщиками, которые в силу различных причин не заявляют свое право на него. Этот вывод подтверждается и низкой долей вычета на благотворительность в общем объеме социальных вычетов, предоставленных налогоплательщикам в РФ - средняя за 11 лет доля вычетов на благотворительность в общем объеме социальных вычетов составила 2,5\%, однако темп

Таблица 4

\section{Основные показатели, характеризующие практику применения налогового вычета} по благотворительности в РФ за период с 2009 по 2019 г.

\begin{tabular}{|c|c|c|c|c|c|c|c|c|c|c|c|}
\hline Показатель & 2009 & 2010 & 2011 & 2012 & 2013 & 2014 & 2015 & 2016 & 2017 & 2018 & 2019 \\
\hline $\begin{array}{l}\text { Количество } \\
\text { налогоплательщиков, } \\
\text { представивших налоговую } \\
\text { декларацию, тыс. чел. }\end{array}$ & 5776 & 4812 & 6094 & 6409 & 6606 & 7043 & 7122 & 7186 & 7436 & 8064 & 8508 \\
\hline $\begin{array}{l}\text { Количество } \\
\text { налогоплательщиков, } \\
\text { которым предоставлены } \\
\text { социальные налоговые } \\
\text { вычеты по } \\
\text { пожертвованиям, чел. }\end{array}$ & 4132 & 3975 & 3351 & 4109 & 4578 & 5316 & 6251 & 7162 & 8436 & 9592 & 9913 \\
\hline $\begin{array}{l}\text { Доля налогоплательщиков, } \\
\text { которым предоставлены } \\
\text { социальные налоговые } \\
\text { вычеты по } \\
\text { пожертвованиям, в общем } \\
\text { количестве } \\
\text { налогоплательщиков, } \\
\text { представивших налоговую } \\
\text { декларацию, \% }\end{array}$ & 0,07 & 0,08 & 0,05 & 0,06 & 0,07 & 0,08 & 0,09 & 0,10 & 0,11 & 0,12 & 0,12 \\
\hline $\begin{array}{l}\text { Общая сумма } \\
\text { предоставленных } \\
\text { социальных налоговых } \\
\text { вычетов, млн руб. }\end{array}$ & 42305 & 45231 & 47143 & 51198 & 57013 & 66100 & 77408 & 86248 & 98418 & 114134 & 109698 \\
\hline $\begin{array}{l}\text { Общая сумма социальных } \\
\text { налоговых вычетов по } \\
\text { пожертвованиям, млн руб. }\end{array}$ & 504 & 376 & 566 & 1274 & 1487 & 1624 & 2207 & 2139 & 4450 & 3749 & 3952 \\
\hline $\begin{array}{l}\text { Доля социального } \\
\text { налогового вычета по } \\
\text { пожертвованиям в общем } \\
\text { объеме социальных } \\
\text { налоговых вычетов, \% }\end{array}$ & 1,19 & 0,83 & 1,20 & 2,49 & 2,61 & 2,46 & 2,85 & 2,48 & 4,52 & 3,28 & 3,6 \\
\hline
\end{tabular}

Источник. Составлена автором на основании данных ФНС РФ по формам статистической налоговой отчетности. Данные по формам статистической налоговой отчетности. URL: https://www.nalog.ru/rn77/ related_activities/statistics_and_analytics/forms/ 
их роста за период с 2009 по 2019 г. составил 7,8 раза.

Интересным является сопоставление средней суммы вычетов на благотворительность на одного налогоплательщика за 11 лет (300 тыс. руб.) со средней величиной пожертвований физических лиц, согласно их опросам (3 тыс. руб.). Можно сделать вывод, что подавляющее большинство россиян, осуществляющих пожертвования в небольших суммах, не видят смысла в сборе документов, подтверждающих право на вычет. Действительно, возврат налога в сумме 390 руб. (примерно 5 долл. США, при расчете от средней суммы пожертвований) не является значимым для благотворителей. Интерес к налоговому вычету проявляют преимущественно лица, делающие благотворительные взносы в больших суммах (возврат налога в сумме 39000 руб. от средней суммы пожертвований, заявленных в качестве налогового вычета (300 000 руб.), уже представляется целесообразным). Следствием того, что россияне не обращаются за вычетом на благотворительность, являются и не очень высокие (по сравнению с иными вычетами) налоговые расходы государства в связи с ним: по итогам 2019 г. они составили 513,8 млн руб.

Низкая востребованность социального вычета на благотворительность у населения России объясняется не только тем, что суммы пожертвований в среднем не очень велики и не возникает экономического стимула к его оформлению на основании подачи декларации по НДФЛ. Одной из основных причин неоформления гражданами налогового вычета является их недостаточная информированность - 33\% россиян в принципе не знают о своих правах на получение льгот по налогам и 44\% не знают, как подать декларацию о доходах ${ }^{11}$. Кроме того, дополнительные трудности в получении вычета возникают в связи со сложностью и трудоемкостью процесса сбора комплекта документов, необходимых для получения вычета. Ситуация усугубляется тем, что главной формой осуществления пожертвований являются онлайн-

${ }^{11}$ Исследование ЦСР «Налоги глазами россиян». URL: https://www.csr.ru/upload/iblock/029/029a94c47e0e9a7c 374683d0169beaad.pdf переводы: в 2019 г. они составили 43\% от общего объема благотворительной помощи, выраженной в передаче денег, в том числе $16 \%$ - доля пожертвований через электронные кошельки Apple Pay, PayPal и Google Wallet. Часто денежные переводы проходят через такие платежные сервисы, по которым банки не предоставляют платежные поручения, поэтому подтвердить факт благотворительности не представляется возможным. Чрезмерная забюрократизированность процесса оформления налоговых вычетов в России является признанной проблемой, которую постепенно решают благодаря развитию технологий налогового администрирования.

На основании низкой востребованности налогового вычета по пожертвованиям можно говорить о неэффективности в России поддержки благотворительности налоговыми методами. Усиление налогового стимулирования частной благотворительности заявлено в Концепции содействия развитию благотворительной деятельности в РФ на период до 2025 г. Расширение налоговых стимулов участия в благотворительности граждан предполагается осуществлять в том числе и за счет предоставления возможности перечисления по заявлению налогоплательщика суммы налога на доходы физических лиц, подлежащего возврату в связи с социальным налоговым вычетом по осуществляемым им благотворительным пожертвованиям, некоммерческим организациям - получателям пожертвований. Этот механизм (Gift Aid) является очень перспективным и широко применяется в мировой практике.

Суть схемы Gift Aid состоит в том, что физическое лицо-благотворитель отказывается от получения налогового вычета по совершенным пожертвованиям и передает право получить возврат налога из бюджета тому лицу, которое является получателем помощи. Такой подход основан на утверждении, что любые денежные пожертвования, которые налогоплательщик перечисляет благотворительной организации, сделаны после уплаты подоходного налога, и благотворительная организация может вернуть налог с суммы пожертвования. Таким образом, сумма пожертвования для получателя (например, некоммерческой органи- 
зации) возрастает на сумму налога на доходы физических лиц, уплаченного с доходов, направленных на благотворительность, т. е. жертвуется не только определенная сумма, но и налоговый вычет с нее.

Впервые схема Gift Aid была введена в Великобритании в 1990 г. и предназначалась только для денежных пожертвований, однако с 2006 г. она была распространена и на подарки нуждающимся, оплачиваемые физическими лицами в магазинах, реализующих товары с благотворительной целью. Первоначально схема Gift Aid работала только на основании декларации, которую налогоплательщик, пусть и в упрощенной форме, но все-таки должен был заполнить, а впоследствии перешли к практике устного заявления налогоплательщика о намерении пожертвовать вычет, но благотворительная организация должна получить в письменной форме подтверждение у налогоплательщика этого заявления. Схема Gift Aid может быть реализована только в отношении конкретного налогоплательщика и невозможна в отношении человека, собирающего коллективные пожертвования и затем передающего их благотворительной организации. Также эта схема не применяется в случае, если жертвователь получил что-то взамен, например, при покупке для себя товаров в благотворительном магазине или билета в благотворительном розыгрыше.

Схема Gift Aid показала высокую эффективность в Великобритании и в 2010 г. была введена в странах - членах Европейского союза, Норвегии и Исландии, в 2014 г. - в Лихтенштейне. В рамках схемы Gift Aid в 2014/2015 финансовом году сумма налога, перечисленного благотворительным организациям в Великобритании, составила 1,19 млрд фунтов стерлингов ${ }^{12}$. Безусловно, реализация такой масштабной схемы возврата налога требует высокого качества налогового администрирования и контроля, так как во всем мире существует проблема мошеннических схем получения средств из бюджета.

В соответствии с исследованием, проведенным рабочей группой по налоговым

${ }_{12}$ Total Gift Aid received by charities rose by $\mathrm{J} 140 \mathrm{~m}$ last year. URL: https://www.thirdsector.co.uk/total-gift-aidreceived-charities-rose-140m-last-year/finance/article/1362083 преступлениям и отмыванию денег ОЭСР ${ }^{13}$, уклонение от уплаты налогов благотворительными организациями является серьезным и растущим риском во многих странах. На основе изучения ситуации в 19 стра$\operatorname{нax}^{14}$ в 2008 г. был сделан вывод о том, что налоговые злоупотребления благотворительными организациями наносят ущерб государственным бюджетам в сотни миллионов долларов и становятся все более распространенными, организованными и продуманными. Налоговые органы выявили несколько способов уклонения от уплаты налогов и отмывания денег благотворительными организациями. Наиболее часто отмечаются следующие ситуации:

организация не зарегистрирована в качестве благотворительной, но осуществляет сбор средств и использует налоговые льготы;

зарегистрированная благотворительная организация умышленно участвует в схеме уклонения от уплаты налогов в личных интересах своих организаторов и/или доноров;

благотворительная организация оказывается замешанной в налоговом мошенничестве неосознанно за счет незаконных действий третьих лиц, таких как недобросовестный составитель налоговой декларации, который подготовил и представил поддельные документы об осуществлении пожертвований;

благотворительные организации осуществляют выдачу поддельных квитанций о пожертвованиях, квитанций физическим лицам, работающим в организации-бенефициаре, и квитанций с завышенной стоимостью пожертвованных активов.

Налоговые органы за рубежом сочетают сбор данных о благотворительных организациях и их жертвователях, проактивный анализ и профилирование рисков, а также сопоставление данных налоговых органов и других государственных учреждений для выявления случаев налогового мошенничества и/или отмывания денег при подозре-

13 URL: https://www.oecd.org/tax/exchange-of-taxinformation/42232037.pdf

${ }_{14}$ Исследование проводилось в Австрии, Аргентине, Бельгии, Германии, Дании, Ирландии, Испании, Италии, Канаде, Нидерландах, Норвегии, Португалии, Великобритании, США, Турции, Франции, Чешской Республике, Чили и Швеции. 
нии на злоупотребления. Такие подозрения могут возникнуть, если отмечаются следующие так называемые «индикаторы красного флага»:

налогоплательщик - физическое лицо декларирует низкий или умеренный доход с резким изменением структуры пожертвований либо вообще не имеет истории пожертвований и внезапно делает благотворительные пожертвования в значительных суммах;

доля пожертвований в доходах высока, осуществляется множество благотворительных выплат без видимой связи;

многие доноры имеют одинаковое сообщество или культурное происхождение, работают вместе по схожим направлениям работы или в одной крупной компании;

значительная часть пожертвований осуществляется наличными, что затрудняет их отслеживание;

налогоплательщик не дает ответа на запросы, предоставляет копии, а не оригиналы квитанций о благотворительных пожертвованиях, квитанции оформлены с нарушениями;

налогоплательщик сделал благотворительные пожертвования в сумме менее 500 долл. США (318 евро) или более 3000 долл. США (1912 евро) в течение одного налогового периода;

налоговый вычет равен или превышает 1000 долл. США (637 евро).

Как отмечается в исследовании, решающее значение для выявления и расследования таких случаев имеет эффективный обмен информацией между налоговыми органами, другими национальными ведомствами и правоохранительными органами. Для совершенствования налогового контроля за благотворительными организациями, как правило, осуществляется ведение центрального реестра всех подозрительных действий для выявления и анализа тенденций в этой сфере; постоянно актуализируется информация об уровне налогового риска; формируются кросс-функциональные команды проверяющих; внедряется автоматизированная система перекрестной проверки налоговыми, правоохранительными и иными государственными органами и т. п.
Опыт развитых стран в части порядка предоставления налоговых вычетов, администрирования и налогового контроля благотворительных организаций и физических лиц, осуществляющих пожертвования, может быть использован и в России, где вычет на благотворительность имеется, но является недостаточно востребованным населением, и в Беларуси, где граждане активно участвуют в благотворительности, но не установлено налогового механизма, поддерживающего их в этом начинании.

Безусловно, для того чтобы заменить обязанность налогоплательщиков - физических лиц по документальному подтверждению своего права на налоговые вычеты подтверждением этого права налоговыми органами, необходимо создать систему информационного взаимодействия налоговых органов с внешними источниками данных (банками, благотворительными организациями и др.), а также автоматизированную систему обработки поступившей в налоговые органы информации о расходах на благотворительность. Все это требует дальнейшей цифровизации процессов налогового администрирования, совершенствования законодательных актов и алгоритмов работы налоговых органов. При передаче некоторых прав по изменению федерального законодательства в части налоговых вычетов на благотворительность на региональный уровень (как это сделано в России) возникают дополнительные нюансы, касающиеся необходимости принятия выверенных и рациональных региональных законов, а также организации контроля за правильностью их применения. Для того чтобы налоговые методы поддержки благотворительности были востребованы широким кругом жертвователей и действительно выполняли свое предназначение - поддерживать население в социально значимой деятельности, необходимо широко информировать граждан о наличии права на такой вычет, упрощать процедуру сбора документов, подключая к подтверждению факта передачи пожертвований благотворительные организации, организовывать получение налоговыми органами информации системы банковских платежей об осуществленных пожертвованиях и использо- 
вать различные механизмы социальных налоговых вычетов.

\section{СПИСОК ЛИТЕРАТУРЫ (REFERENCES)}

Горский А.А. 2020. Развитие благотворительности на основе налогового стимулирования: обзор зарубежной практики. Вестник БИСТ (Башкирского института сощиальных технологuй). № 3. C. 75-80. [Gorsky A.A. 2020.
Development of charity based on tax incentives: Review of foreign practice. Vestnik BIST (Bashkirskogo instituta sotsial'nykh tekhnologiy). No3. PP. 75-80. (In Russ.)]

Kireenko A., Golovan S. 2016. Feasibility of the charitable tax deduction introduction in the Russian Federation. Journal of Tax Reform. Vol. 2. No 2. PP. 111-125.

Yanni Zeng. 2019. Tax deduction of crossborder charities: should cross-border philanthropy be given domestic tax treatment? Science and world. Vol. I. No 1. PP. 60-67.

\section{THE ISSUE OF TAX DEDUCTION GRANTING DUE TO CHARITY EXPENSES AMONG CITIZENS}

\section{Elena Firsova ${ }^{1}$}

Author affiliation: ${ }^{1}$ St. Petersburg State University of Economics (St. Petersburg, Russia).

Corresponding author: Elena Firsova (firsova.e@unecon.ru).

ABSTRACT. The article reveals the concept of tax deduction and investigates the issue of its appliance while dealing with the collection of tax on individual income in part of charity expenses. With the experience of foreign countries on tax deduction being analyzed we estimated its global prevalence, classified its key features, generalized the problem span for management and control. Reasons for insufficient demand of such a tax in Russia are substantiated; lines for legislation advancement are suggested to reach more effective tax support of private charity.

KEYWORDS: charity, tax deduction, the Republic of Belarus, Russia, Gift Aid.

JEL-code: H24, H26.

DOI: $10.46782 / 1818-4510-2021-2-136-146$

Received 28.04.2021 